\title{
Endüstriyel Enformasyonun Kıbrıs Türk Endüstrisiyle Buluşması: Farkındalık ve Gereksinme Düzeyi*
}

\section{Confrontation of the Industrial Information with the Cyprus Turkish Industry: Awareness and the Level of Needs}

\author{
Ayşe OKTAN**
}

\begin{abstract}
Öz
Bu çalışmada, Kuzey Kıbrıs Türk Cumhuriyeti (KKTC) ekonomisine dayalı endüstri kuruluşları üzerine, onların enformasyon ihtiyaçlarının anlaşılmasına yönelik bir araştırma yapılmıştır. Bu bağlamda ilgili kurumların mevcut durumu ve gelişimi incelenmiştir. Bunun yanında endüstriyel enformasyonun önemi üzerinde durularak, KKTC'de genel imalat ve kâğı ürünleri ile matbaa sanayisinde endüstriyel enformasyon üzerine olan farkındalık ile endüstriyel enformasyonun gereksinme düzeyleri tespit edilmeye çalışılmıştır.
\end{abstract}

Anahtar sözcükler: Endüstriyel enformasyon, Kuzey Kıbrıs Türk Cumhuriyeti

\section{Abstract}

Turkish Republic of Northern Cyprus's (TRNC) economy based on the Cyprus Turkish industry and firms have been investigated in this study. The importance of industrial information also has been highlighted in the context of Cyprus Turkish industry. The awareness on general production for the paperwork industry in the frame of information industry tries to determine. Moreover, the level of information needs is determined on those sectors.

Keywords: Industrial information, Turkish Republic of Northern Cyprus

\section{Giriş}

Günümüzde ülkelerin gelişmişlik düzeyleri, bilgilenme etkinliği ve bilgi üretimleri ile ölçülmektedir. Bir gelişmişlik ölçütü olan bilgi üretimi, endüstri alanında geliştirilen politikaların etkinliğiyle paralel orantıda bulunmaktadır. İşte bu noktada endüstriyel enformasyon endüstriler için çok büyük önem taşımaktadır. Endüstriyel enformasyonu gereksinim duyanlara aktarma görevi, kütüphanelerin, enformasyon ve dokümantasyon merkezleri ile diğer bilgi merkezlerinin görevidir.

* Bu çalışma, 20 Ekim 2011 tarihinde ÜNAK İkibin11 'Bilgiyi Sanayileştirmek: İnovasyona Dayalı Yeni Değer Ağı' adlı toplantıda sunulan bildirinin genişletilmiş biçimidir.

* Uzman; Yakın Doğu Üniversitesi Bilgi ve Belge Yönetimi Bölümü ve Atatürk Öğretmen Akademisi Kütüphanesi, Lefkoşa, Kuzey Kıbrıs Türk Cumhuriyeti. (ayse.oktan@aoa.edu.tr) 
Bu bağlamda bu çalışmada, Kıbrıs Türk endüstrisi ele alınarak, tarihsel gelişimi ile bugünü hakkında bilgiler verilmeye çalışılmıştır. Daha sonra bir örneklem grubu oluşturulmuş ve bu örneklem grubu üzerinde, işletmeler için büyük önem taşımakta olan endüstriyel enformasyona olan farkındalık ve gereksinme düzeyleri tespit edilmeye çalışılmıştır.

\section{Enformasyon ve Endüstriyel Enformasyon Tanımları}

Enformasyon terimi, Bekir Kemal Ataman'ın Arşivcilik Terimler Sözlüğü'nde (Ataman, 1995, s.34) 'kayıtlı veri, bilgi de denir' şeklinde tanımlanmaktadır. Erhan Arda'nın Ekonomi Sözlüğü'nde (2002) ise enformasyon sözcüğü dar anlamda 'haber ya da bilgi' anlamına gelmektedir. 20. yüzyılın ikinci yarısından sonra terimin anlamının genişlediğinden ve yaygın bir kullanım alanı bulduğundan bahsedilmektedir. Yine aynı sözlükte enformasyon terimi geniş anlamda 'belli bir anda ve belli bir toplumda bilgi ve haberlerin yayılmasına olanak sağlayan araçların tümüne verilen addır'.

Enformasyon terimi, birçok kaynakta 'bilgi' şeklinde tanımlanmakta veya enformasyon terimine karşılık olarak 'bilgi' terimi kullanılmaktadır. Ancak enformasyon (information) ve bilgi (knowledge) terimleri yapıları ve içerdikleri bağlama özgü olarak birbirlerinden farklılık göstermektedir.

Enformasyon daha çok somut bir olgu iken, bilgi genellikle bireylerin zihninde yer alan soyut enformasyondan oluşmaktadır. Bu özelliğe bağlı olarak genellikle enformasyon, sesli, görüntülü vb. bilgi kayıt ortamları üzerinde yer alırken, bilgi daha çok bireylerin zihinlerinde yerleşik olarak bulunur (Odabaş, 2006, s.1).

Enformasyon, istenen veya aranan bir bilgidir (İskeçeli, s.93) ve enformasyon var olan bilginin istenmesi veya aranmasıdır.

Gürdal (1991, s.104), "Endüstriyel Enformasyon ve Türkiye" adlı çalışmasında enformasyon terimini özetle, anlaşılabilir organize edilmiş bilgi ve bu bilginin iletimidir şeklinde tanımlamıştır. Yine aynı çalışmada 'endüstriyel enformasyon' kavramı, endüstriyel işletmelerin finansman, ekonomi, pazarlama, uygun teknoloji kullanımı ile üretim düzeyini arttırma, doğal kaynaklar ve çevreyi tanıma, koruma, birimdeki iç iletişimi sağlama konularında gereksinim duyulan bilgi ve bilgi iletiminde kullandıkları tüm işlem ve yöntemler, endüstriyel enformasyon olarak tanımlanmaktadır.

Endüstriyel enformasyon çok genel bir ifade ile "endüstri ile ilgili organize edilmiş, anlaşılabilir ve/veya kullanılabilir hale getirilmiş bilgi ve bu bilginin uygun kanal ile iletimi"dir (Gürdal, 2000, s.12). Endüstri ise, hammaddeleri yapılmış, madde haline getirmek için gerçekleştirilen üretim ve üretimde kullanılan araçların tümü, dar anlamda yapımcılığı (imalatçılığı), geniş anlamda bir müteşebbisin kurduğu kâr sağlayıcı mal ve hizmet üretimini dile getirir (Hançerlioğlu, 2004, s.353).

Kısaca endüstriyel enformasyon, endüstrinin ihtiyaç duyduğu verilerin ihtiyaç sahiplerine, onların gereksinimleri doğrultusunda düzenlenerek sunulduğu 
düzenlenmiş veriler bütünü şeklinde tanımlanabilir. Burada enformasyon kelimesi genellikle hedef kitlenin ihtiyaç duyduğu biçimde nesnel bir gerçeklik olarak ontolojik boyutta değerlendirilebilir. Bu özelliğinden dolayı bilgiden farklılaşmıştır. Çalışmadaki örnek üzerinden gidilecek olursa endüstri sektöründeki firmaların ihtiyaç duyduğu her türlü verinin, onların ihtiyaçlarını karşılayacak şekilde düzenlenerek enformasyona dönüştürülmesi ve endüstri verilerinin bir araya getirilmesi 'endüstriyel enformasyon' olarak ifade edilebilir.

\section{Endüstriyel İşletmelerde Endüstriyel Enformasyonun Kullanım Alanları}

Toplumun bütün bireyleri ve bütün kuruluşları birer enformasyon kullanıcısıdır. Çünkü toplum içerisindeki birey ve kuruluşlar enformasyonu aramakta ve ona ulaşma çabası göstermektedir. Bu duruma bağlı olarak, endüstriyel işletmelerde çalışan kişiler de birer enformasyon kullanıcısı konumundadırlar.

Endüstriyel işletmelerde çalışan kişiler, bulundukları endüstri kuruluşuna hizmet etmekte ve endüstrilerin amacı olan üretim yapma konusunda enformasyona gereksinim duymaktadır. Tam bu noktada doğru enformasyonu kullanması Gürdal'ın (2000) değişiyle büyük önem arz etmektedir. Bu durumda enformasyon, endüstri ve sanayi kuruluşları için hayati önem taşımaktadır. Çünkü endüstriyel işletmeler çabalarını başta para olmak üzere; insan gücü, hammadde ve enerji gibi kaynakları ve zamanı daha az kullanarak daha kaliteli üretim yapma yönünde yoğunlaştırmaktadır (Gürdal, 2000, s.11).

İşletmeler, hem var olan durumlarını korumak ve iyileştirmek için alınması gereken günlük kararlarda hem de geleceğe yönelik olarak tasarlanan yenilikler için alınacak stratejik kararlarda enformasyonu kullanmalıdır.

Bir endüstriyel işletmede endüstriyel enformasyona şu konularda gereksinim duyulmaktadır (Gürdal, 2000, s.34):

$\diamond$ Finansman

$\diamond$ Hammadde

$\diamond$ İnsan gücü

$\diamond$ Çalışma yeri

$\diamond$ Mevzuat

$\diamond$ Standart

$\diamond$ Teknoloji

$\diamond$ Yönetim

$\diamond$ Çevre Koruma

$\diamond$ Pazarlama 
Bunlarla birlikte bir endüstri işletmesi içerisinde bulunan her bir birimin örneğin insan kaynakları, pazarlama, satış, müşteri ilişkileri yönetimi, tedarik zinciri yönetimi, üretim yönetimi, lojistik yönetimi, ürün tasarımı ve enformasyon teknolojileri ile finansman ve muhasebe yönetimi birimlerinin varlıklarını ve işlevlerini sürdürebilmelerinde enformasyona ihtiyaç duydukları göz ardı edilmemelidir. Sadece işletmenin yönetim ayağındaki işlevinin değil; pazarlama, üretim yönetimi ve finans - muhasebe işlevlerinin de enformasyona ihtiyaç duyduğu bir gerçektir. Bu açıdan bakıldığında işletmelerde verinin enformasyona dönüştürülmesi işleriyle ilgilenen bir pozisyona ihtiyaç duydukları bir aşikârdır. Endüstriyel enformasyonun oluşumu ancak bu pozisyon sayesinde hız kazanabilir. Buna ek olarak, yönetimin işlevleri içerisinde değerlendirdiğimiz planlama, örgütleme, yöneltme ve denetim gibi işlevlerinin örgüt içerisinde gerçekleşebimesi için de enformasyona gereksinme duyulduğu söylenebilir. Endüstriyel enformasyon tam bu noktada, ilgili işlevlerin ötgüt içerisinde başarıya ulaşmasında hammadde rolü üstlenmektedir.

\section{Kıbrıs'ta Endüstrileşme Süreci ve Kıbrıs Türk Endüstrisinin Gelişimi}

İnsanlık tarihi geçmişten günümüze önemli devrim ve dönüşümler yaşamış, bu önemli dönüşümlerden biri de 'Endüstri / Sanayi Devrimi' olmuştur.

Sanayileşme, 18. yüzyıl İngiltere'sindeki insanların yaşamlarını sürdürdükleri araçları etkileyen karmaşık bir teknolojik değişimler kümesinin kısa adı olan sanayi (endüstri) devrimiyle başlamıştır (Kocacık, 2003, s.2).

İngiliz Sanayi Devrimi'nin ardından günümüze bakıldığında, sanayi toplumlarının hem toplumsal, hem ekonomik hem de siyasi anlamda yeni bir toplumsal dönüşüm içerisinde olduğu görülmektedir. Bu dönüşüm 'bilgi' ve/veya 'enformasyon' çağı olarak ve sanayi toplumları 'bilgi toplumu' ve/veya 'enformasyon toplumu' olarak adlandırılmaktadır. Bu gelişmeler ışığında, enformasyon toplumu özelinde Kıbrıs Türk endüstrisinin tarihi ve gelişimi irdelenmesi gerekir.

Kıbrıs Türk endüstrinin tarihi ve gelişimi ile ilgili bilgiler, görüşme yöntemi kullanılarak ve gelişime ışık tutmuş ya da bu gelişim içerisinde yer almış olan bazı kişilerle görüşülerek elde edilmeye çalışıımıştır. Bu kapsamda Kıbrıs Türk Sanayi Odası'ndan Sanayi Sektörünü Geliştirme Asistanı Hilmi Numan, Hilmi Toros Endüstri Ltd. işletmeci ve sahibi Emine Akın Numan, KKTC Rekabet Kurulu Başkan Yardımcısı Mustafa Gündüz ve TAŞOVA (Taş Ocakları Vakfı) Genel Sekreteri Halil Erdim ile görüşülmüştür.

Halil Erdim' den* elde edilen bilgilere göre, kendisinin Kıbrıs Türkü'nün endüstrileşme sürecine ilişkin yapmış olduğu araştırma ve röportajlarda I. Dünya Savaşına kadar

* Görüşme - Halil Erdim (Ağustos 2011). 
olan bilgilere ulaşılmış olduğu görülmektedir. Şu anda TAŞOVA Genel Sekreteri olan Halil Erdim'in kendisinden elde edilen bilgilere göre, Kıbrıs'taki endüstrinin gelişimini engelleyen birçok etken vardır. Bunlar:

$\diamond$ Sömürge yönetimi ve yönetimin yönlendirmesi

$\diamond$ Savaşlar (I. Ve II. Dünya Savaşları, Süveyş Savaşı, 1963 olayları ve 1974 Barış Harekatı)

$\diamond$ İki toplumda bulunan aşırı milliyetçi unsurların baskıları, tedhiş hareketleri

$\diamond$ Ambargolar, ayırımcılık

$\diamond$ Fakirlik, ulaşım sorunları, eğitim eksikliği

$\diamond$ Uluslararası eğilimler, teknolojik gelişmeler, ihtiyaçların artması

$\diamond$ Doğal afetler, iş kazaları

$\diamond$ Türkiye ile yaşanan ilişkiler

Halil Erdim'in röportaj yoluyla elde edilen bilgilere göre, adada sömürge yönetiminin olduğu dönemde, yönetimin askere ihtiyacı olması nedeniyle yatırım alanındaki ihaleleri azaltmış ya da durdurmuş ve askerliği daha cazip, geliri olan bir meslek durumuna getirmiştir. Böylece insanlar sanayi yönünde yatırım yapmak yerine asker olmayı tercih etmiş, gerek savaş dönemi gerekse savaş sonrasında, yönetim, yeni doğan ihtiyaçlara göre toplumu yönlendirmeye başlamıştır.

Sömürge döneminde yaşanan bu yönlendirmelerin yanında dünyada ve adada yaşanan savaşlar sanayinin gelişmesine büyük engel oluşturmuştur. Çok sayıda insan savaşlarda ölmüş, yatırımcılar, yetişmiş veya genç insan gücü savaşlar nedeniyle kaybedilmiştir. Bunun yanında savaş sırasında birçok yatırımı fabrikasını, ekipmanlarını, hammadde ve mamüllerini kaybetmiştir. Özellikle 1974 Barış Harekâtı sonrasında Güney Kıbrıs'tan Kuzey Kıbrıs'a göç edenlerin üretim araçları Güney Kıbrıs'ta kalmış ve üreticiler büyük kayıplar yaşamıştır.

Milliyetçi unsurların baskıları, tedhiş hareketleri de sanayinin gelişmesini olumsuz etkilemiştir. Örneğin EOKA olayları sırasında tedhiş örgütü, Rum işverenlere baskı yapmış, yanlarında çalıştırdıkları Türk işçileri işten çıkarmaları konusunda tehdit etmiştir. Bunun yanında birçok Türk yatırımcı, Rum kesimindeki iş yerini terk edip Türk kesiminde yeni işyeri açmak zorunda kalmıştır.

Halen toplumumuza uygulanmakta olan ambargolar o dönemde varlığını sürdürmekte ve Türk yatırımcılara engellemeler yapılmaktaydı. Türklerin fabrika kurması olağan dışı olarak karşılanmakta ve bu girişimleri engellemekteydi.

1963 - 1968 yılları arasında Kıbrıs Rum Yönetiminin uyguladığı ayrımcılık politikalarıyla, Kıbrıslı Türklere her çeşit malın satılması yasaklanıyordu. Örneğin mevzi yapılmasını engellemek bahanesiyle her türlü inşaat malzemesinin Türklere satılması yasaklanmıştı. 
Bunların yanında Kıbrıslı Türklerin yaşamış olduğu maddi sıkıntılar, fakirlik, eğitim eksiklikleri, ulaşımda yaşadıkları sorunlar da Kıbrıs Türkü'nün endüstri alanında gelişmesini engellemiştir.

Türkiye ile yaşanan ilişkiler de endüstrinin gelişmesini olumsuz yönde etkilemiştir. Kıbrıs'a Türkiye'den işçi getirip çalıştırma olayları 1960'lı yıllara dayanmaktadır. Halil Erdim'in o dönem Limasol'da matbaası olan Şevket Ali Sürel'den öğrendiği ilginç bir hikâyede, Şevket Ali Sürel'in okul defteri üretmek amacıyla Türkiye'den iki usta getirmek için onları Kıbrıslı Türk kadınlarla evlendirmek zorunda kaldığı olayı vardır. Diğer yandan Türkiyeli iş adamlarının bilmedikleri, görmedikleri ürünleri adaya gelerek öğrenmesi ve Türkiye'de üretmeye başlaması, Kıbrıslı Türklerin Türkiye'ye ihracat yapmasını engellemeye başlamıştır.

1975 'te KKTC'yi ziyarete gelen Bülent Ecevit ve bir grup iş adamı Haspolat'taki sanayi bölgesini ziyaret etmiş ve gördükleri tesis ve ürünler karşısında hayrete düşmüştür. O dönem Türkiye'de aleminyum kapı - pencere bilinmiyordu. Çimento ve kireç fabrikalarında kâğıt torba üreten fabrikalar, güneş enerjisiyle çalışan su ısıtıcıları onlar için büyük bir yenilikti.

\section{KKTC Ekonomisi ve Kıbrıs Türk Endüstrisinin Bugünü}

\section{KKTC Ekonomisi}

Yukarıdaki bölümde Kıbrıs Türk endüstrisinin gelişimi ile ilgili bilgiler verilmeye çalışılmıştır. Kıbrıs Türk endüstrisinin günümüzdeki durumu hakkında bilgi vermeden önce KKTC ekonomisine değinmekte yarar vardır.

Kuzey Kıbrıs'ta serbest piyasa ekonomisi benimsenmiştir. Para birimi olarak da 'Türk Lirası (TL)' kullanılmaktadır. Birleşmiş Milletler tarafından 2003 yılında geliştirilen ve tartışılan "Kıbrıs sorununa kapsamlı bir çözüm bulunması" planı ve adanın Kuzey ve Güneyi arasında geçişleri sağlayan kapıların açılması, yatırım ortamında olumlu gelişmelerin tetikleyici gücü olmuştur. Ayrıca, adanın her iki tarafındaki hükümetlerin uyguladığı olumlu siyasi politikalar, son dönemlerde Türk Lirası'nın istikrara kavuşması gibi birçok gelişme sonucunda Kuzey Kıbrıs ekonomisinin görünümü "olumluya" dönmüştür. Kıbrıs Türk Yatırım Geliştirme Ajansı'ndan elde edilen bilgilere göre, yatırım iklimindeki iyileşmeler sonucunda, 2003-2009 döneminde Avrupa ülkeleri arasında en hızlı büyüyen ekonomilerden biri olan Kuzey Kıbrıs, bu dönemde ortalama \%6,47 oranında büyümüştür (Kıbrıs Türk Yatırım Geliştirme Ajansı, 2011). 


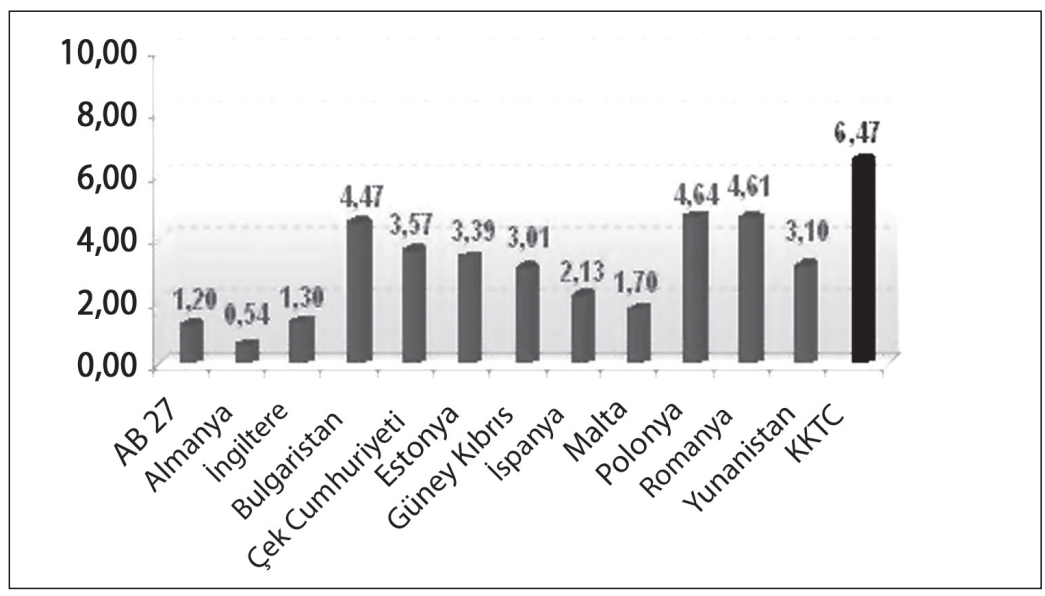

Şekil 1. 2003-2009 Yılları Arasında Kuzey Kıbrıs ve Avrupa Ülkelerinin Büyüme Oranları (\%) Kaynak: Devlet Planlama Örgütü, 2010; Eurostat, 2010

Küçük bir ekonomisi olan Kuzey Kıbrıs, Avrupa Birliği ülkelerine kıyasla en yüksek büyüme oranına sahip ülkelerden biridir. Bu da yatırımcılar için önemli bir potansiyel avantaj sağlamaktadır (Kıbrıs Türk Yatırım Geliştirme Ajansı, 2011).

Çalışma hayatı içerisinde önemli bir yeri olan ve vasıfsız bir işçinin ortalama ücretinin ekonomik nedenlerle sosyal yönden kabul edilmez bir düzeye inmesini önlemek temel amacına yönelik olarak asgari ücret tespit edilmektedir. KKTC'de 2008 yılının Ocak Ağustos döneminde 1,060 TL olarak uygulanan asgari ücret Eylül ayından itibaren 1,190 TL olarak tespit edilerek uygulanmıştır (Devlet Planlama Örgütü [DPÖ], 2010, s.201).

KKTC Merkez Bankası verilerine göre Kuzey Kıbrıs'ta 1 kamu mevduat bankası, 16 özel sermayeli banka, Türkiye kökenli 7 şube bankası, 1 kalkınma ve yatırım bankası, 7 tane Tasarruf Mevduatı Sigorta Fonu (T.M.S.F.) bankası, 6 tane de tasfiye halinde banka bulunmaktadır. Merkez Bankası'ndan elde edilen bilgilere göre 2009 yılında toplam mevduat 6.5 milyar \$ düzeylerine ulaşmıştır (KKTC Merkez Bankası, 2011).

KKTC ekonomisinde önemli bir rol oynayan tarım sektörüne bakıldığında, tarım sektöründe yaşanan olumsuzlukların hafifletilmesine olanak sağlamak amacıyla Kuzey Kıbrıs Türk Cumhuriyeti ile Türkiye Cumhuriyeti Hükümetleri arasında tarım alanında “Teknik, Bilimsel ve Ekonomik İşbirliği Anlaşması” imzalanmıştır. 24 Ocak 1997 tarihinde imzalanan anlaşma; iki ülkeye uzman, materyal ve araştırma sonuçlarını karşılıklı kullanılma imkânı tanırken, tarımsal pazarlama ve ortak yatııımların teşviki alanında da birlikte hareket etmelerine olanak sağlamaktadır (DPÖ, 2010, s.39). KKTC'de, tarımsal ürünlerin toplam ihracat gelirleri içindeki payı 2009 yılında \%29,7 düzeyindedir. 2009 yılında tarımsal ürünlerin GSYiH' daki payı \%6,4; istihdamdaki payı ise $\% 4,8$ düzeylerindedir. Narenciye, enginar ve Kıbrıs patatesi en önemli tarım ihraç ürünleridir (Kıbrıs Türk Yatııım Geliştirme Ajansı, 2011). 
Tarım sektörünün yanında hayvancılık sektörüne bakıldığı zaman, KKTC'deki hayvan sayısının doyum noktasına ulaşmadığı görülmektedir. Tarımı gelişmiş ülkelerde, tarımsal üretimin büyük bir kısmı hayvancılıktan elde edilirken, KKTC'de hayvancılıküretiminin toplam tarımsal üretim içindeki payı \%35 ile 50 dolaylarında seyretmektedir (DPÖ, 2010, s.44).

Yüksek Öğrenim Sektörü, ödemeler dengesi ve ekonomiye sağladığı katkılarla, Kuzey Kıbrıs'ın en önemli hizmet sektörlerinden biridir. Ülkede, birçok farklı ülkeden öğrencinin eğitim gördüğü 6 üniversite bulunmaktadır (Kıbrıs Türk Yatırım Geliştirme Ajansı, 2011).

Kuzey Kıbrıs'ta, emekli yabancıların yazlık ev satın alma talebi son yıllarda önemli bir artış göstermiştir. Yaklaşık olarak 10 bin yabancı aile Kuzey Kıbrıs'ta yaşamaktadır. Kıbrıs, Birleşmiş Milletler Askerleri ve Koloni Dönemine uzanan Birleşik Krallık ile oluşan güçlü bağları nedeni ile belli ülkeler tarafından çok iyi bilinen bir bölgedir. Özellikle, İngiliz Toplumu Kuzey Kıbrıs'ta çok aktiftir (Kıbrıs Türk Yatırım Geliştirme Ajansı, 2011). Devlet Planlama Örgütü'nden elde edilen verilere göre, inşaat sektörü ekonomideki 27 alt sektörü tetiklemektedir. Buna bağlı olarak inşaat sektöründeki büyümenin ekonomideki yansıması büyük orandadır.

Son yıllarda Kuzey Kıbrıs sektörlerinde önemli düzeyde değiş̧iklikler yaşanmış ve son 30 yılda ekonominin ağırlığı ve yapısı tarım ekonomisinden turizm ve endüstriye doğru bir değişim göstermiştir. Turizm sektörü KKTC'de önemli bir ekonomik paya sahiptir. 2006 ve 2007 yılları itibarıyla KKTC'deki turistik konaklama tesislerinde konaklayan turist sayısı 368,891 ve 423,396; doluluk oranı ise \%33,5 ve \%32,5 olarak gerçekleşmiştir (DPÖ, 2010, s.100). 2008 yılı konaklayan turist sayısı 2006 yılına göre \%29,7 ve 2007 yılına göre ise \%13,0 artış göstermiştir. 2008 yılında net turizm geliri 383.7 milyon \$ olarak gerçekleşmiştir (DPÖ, 2010, s.108).

İmalat sektörü ekonomide 2009 itibariyle \%10 düzeylerinde bir paya sahiptir. İmalat sektörünün 2009 yılında GSYiH'daki payı \%10; istihdamdaki payı ise \%9,1 düzeyindedir (Kıbrıs Türk Yatırım Geliştirme Ajansı, 2011).

\section{Kıbrıs Türk Endüstrisinin Bugünü}

2001 Eylül ayı itibariyle yürürlüğe giren 47/2000 sayılı "Yatırımları Teşvik Yasası" ile sektöre sağlanan finansal ve diğer teşviklerin özel sektör yatırımlarında beklenen gelişmeyi özellikle 2004 ve 2007 dönemi rakamlarına yansıdığı görülmektedir. Türkiye - KKTC arasında sürdürülen KKTC'nin kalkınmasına yönelik çabalar çerçevesinde sanayi sektörüne aktarılması öngörülen finansal teşviklerin KKTC Kalkınma Bankası aracılığı ile kullandırıması yatırım iklimini canlı tutulmasında önemli rol oynamakta ve sektör üzerinde olumlu etki yaratmaktadır. Bu çerçevede sektöre aktarılan finansal teşviklerin artırılarak sürdürülmesi önem arz etmektedir (DPÖ, 2010, s.57).

Sanayi sektöründe üretimde verimliliği artırmak için KKTC'de 2000 yılı başlarında Türkiye Cumhuriyeti Standartlar Enstitüsü temsilciliğinin başlatmış olduğu adımlar vardır (DPÖ, 2010). 
Devlet Planlama Örgütü’nün 2008 yılı “Makroekonomik ve Sektörel Gelişmeler” adlı kaynaktan elde edilen bilgilere göre sanayi sektörünün 2008 yılında katma değerinin cari fiyatlarla diğer yıllara göre \% 26,3 oranda arttığı ve 544,004,053.8 TL'ye ulaştığı; yine aynı kaynaktan elde edilen bilgilere göre 2008 yılında sanayi sektörü dış satımının 47.1 milyon \$ olarak gerçekleştiği görülmektedir.

İhracata bakıldığında, 2003 yılı Nisan ayı itibarıyla kapıların Güney Kıbrıs'a geçişlerin serbest bırakıldığı süreci takip eden 2004-2008yılları arasında Güney Kıbrıs'a az miktarda da olsa bazı sanayi ürünlerinin ihraç edilmesine başlanmış olduğu görülmektedir. Bu ihracat günümüzde artarak devam etmektedir (DPÖ, 2010, s.61).

\section{KKTC Genel İmalat ve Kâğıt Ürünleri ile Matbaa Sanayisinde Endüstriyel Enformasyonun Farkındalık ve Gereksinim Düzeyi}

\section{Yöntem}

KKTC'degenel imalat ve kâğıtürünleriilematbaa sanayisinde endüstriyelenformasyonun farkındalık ve gereksinim düzeyi ölçülürken anket yöntemi kullanılmıştır. Ankette 2000 yılında Oya Gürdal'ın yazdığı 'Tekstil Endüstrisinde Enformasyon Olgusu' adlı kitabında survey (kullanıcı araştırması) çalışmasını yapmış olduğu anket formu esas alınmıştır. Oya Gürdal'ın kitabında tekstil endüstrisi üzerinde uygulanan anket çalışması, KKTC ve bu çalışma için genel imalat ve kâğıt ürünleri ile matbaa sanayisini kapsamaktadır.

Örneklem grubu içerisine giren firmaların yetkilileri ile tek tek görüşülerek anket formu doldurulmuştur. Bu araştırmanın yöntemi, veri toplama tekniği açısından ankete dayanmaktadır. Verilerin analizinde ise Statistical Package for the Social Sciences (SPSS) paket programı kullanılmıştır. Ayrıca literatür taraması ile çalışmanın teorik arka planı verilmeye çalışılmıştır.

\section{Örneklem Büyüklüğü}

Bu çalışma için örneklem grubunu Kıbrıs Türk Sanayi Odası'na üye olan genel imalat ve kâğıt ürünleri ile matbaa sanayisi kuruluşları oluşturmaktadır. Örneklem grubunu oluştururken Kıbrıs Türk Sanayi Odası ile çalışılmış ve sanayi odasına kayıtlı olmayan kuruluşlar örneklem grubu dışında bırakılmıştır.

Genel imalat ve kâğıt ürünleri ile matbaa sanayisinde Kıbrıs Türk Sanayi Odası'na üye toplam 31 sanayi kuruluşu bulunmaktadır.

\section{Bulgular ve Analiz}

Bu aşamada anket formlarından çıkan bulgular analiz edilirken SPSS programının 17. versiyonu kullanılmıştır. Veriler girildikten sonra, tanımlayıcı istatistiklerden sadece frekans tabloları alınmıştır.

Çalışmanın temel bulguları şu şekildedir:

KKTC Genel Imalat ve Kâğıt Ürünleri ile Matbaa Sanayisi Işletmelerinde Bilgi Merkezlerinin Varlığı: 
Bu aşamada, genel imalat ve kâğıt ürünleri ile matbaa sanayisi işletmelerinde bilgi merkezlerinin varlığı tespit edilmeye çalışılmıştır.

Tablo I. KKTC Genel İmalat ve Kâğıt Ürünleri ile Matbaa Sanayisi İşletmelerinde Bilgi Merkezlerinin Varlığı

\begin{tabular}{lcccc}
\hline & Frekans & Yüzde & Geçerli Yüzde & Kümülatif Yüzde \\
\hline Evet (Personel Olan) & 2 & 6,9 & 6,9 & 6,9 \\
Evet (Personeli Olmayan) & 3 & 10,3 & 10,3 & 17,2 \\
Hayır & 24 & 82,8 & 82,8 & 100,0 \\
\hline Toplam & $\mathbf{2 9}$ & $\mathbf{1 0 0 , 0}$ & $\mathbf{1 0 0 , 0}$ & \\
\hline
\end{tabular}

Tablo l'de görüldüğü üzere ankete yanıt veren toplam 29 sanayi kuruluşundan 5 tanesinin bilgi merkezi bulunmaktadır. Bilgi merkezi bulunan bu 5 firmanın 2'sinde personel bulunmasına rağmen üniversite düzeyinde kütüphanecilik ya da bilgi ve belge yönetimi alanında eğitim görmüş personel bulunmamaktadır.

KKTC Genel Imalat ve Kâğıt Ürünleri ile Matbaa Sanayisi Işletmelerinde Bilgi Merkezi Olmayan Kuruluşların Bilgi Gereksinimini Karşılama Yolları:

Bu aşamada, genel imalat ve kâğıt ürünleri ile matbaa sanayisi işletmelerinde bilgi merkezi olmayan kuruluşların, bilgiyi hangi yollarla elde ederek bilgi gereksinimlerini karşıladıkları tespit edilmeye çalışılmıştır.

Tablo II. KKTC Genel İmalat ve Kâğıt Ürünleri ile Matbaa Sanayisi İşletmelerinde Bilgi Merkezi Olmayan Kuruluşların Bilgi Gereksinimini Karşılama Yolları

\begin{tabular}{llcccc}
\hline & Frekans & Yüzde & Geçerli Yüzde & Kümülatif Yüzde \\
\hline Geçerli & Kişisel Çabalarla Oluşturma Derme & 3 & 10,3 & 12,5 & 12,5 \\
& Kurum İçi Bilgisayara Dayalı & 13 & 44,8 & 54,2 & 66,7 \\
& Veritabanları & 1 & 3,4 & 4,2 & 70,8 \\
& Hiçbir Bilgi Kaynağına Gerek Yoktur & 7 & 24,1 & 29,2 & 100,0 \\
& Diğer & 24 & 82,8 & 100,0 & \\
& Toplam & 5 & 17,2 & & \\
Dikkate & & $\mathbf{2 9}$ & $\mathbf{1 0 0 , 0}$ & & \\
alınmayan & Toplam & &
\end{tabular}

Bu aşamada işletmelerinde bilgi merkezi olmayan 24 sanayi kuruluşunun, bilgi gereksinimlerini hangi yollarla karşıladıkları tespit edilmeye çalışılmıştır. Tablo II' de de görüldüğü üzere bilgi merkezi olmayan 13 işletme, kurum içi bilgisayara dayalı veritabanları aracılığıyla bilgi gereksinimlerini karşılamaktadır. 
Çalışma kapsamında 7 işletme diğer seçeneğini işaretlemiş ve anket formlarında da 'diğer' seçeneğinin yanına, internet yoluyla gereksinim duydukları enformasyona eriştiklerini belirtmişlerdir.

Diğer 3 işletme kişisel çabalarıyla oluşturdukları derme ile bilgi gereksinimlerini karşılarken; 1 işletme de hiçbir bilgi kaynağına ihtiyaç duymadığını belirtmiştir.

KKTC Genel Imalat ve Kâğıt Ürünleri ile Matbaa Sanayisi İşletmelerindeki Enformasyon Kullanıcılarının, Enformasyon Hizmetlerini Bilme Durumu:

Bu aşamada, genel imalat ve kâğıt ürünleri ile matbaa sanayisi işletmelerindeki enformasyon kullanıcılarının, enformasyon hizmetlerinden çeviri hizmeti, bilgi kaynaklarının ödünç verilmesi, yöneltme, bilgi merkezleri arası ödünç verme, araştırma ve geliştirme projeleri hakkında enformasyon, çoğaltma, veri toplama, literatür taraması, hazır danışma hizmeti, patent ve standart enformasyonu, yönetim enformasyonu ve diğer enformasyon hizmetlerini bilme durumu ölçülmeye çalışılmıştır. Elde edilen bulgular, aşağıda tablolarla belirtilmektedir.

Tablo III a. Çeviri Hizmeti

\begin{tabular}{llcccc}
\hline & & Frekans & Yüzde & Geçerli Yüzde & Kümülatif Yüzde \\
\hline Geçerli & Evet & 12 & 41,4 & 42,9 & 42,9 \\
& Hayır & 16 & 55,2 & 57,1 & 100,0 \\
& Toplam & 28 & 96,6 & 100,0 & \\
Dikkate & 1 & 3,4 & & \\
Alınmayan & $\mathbf{2 9}$ & $\mathbf{1 0 0 , 0}$ & & \\
\hline Toplam & & & & \\
\hline
\end{tabular}

Tablo Illa' da, anketimize cevap veren 28 işletmedeki 12 enformasyon kullanıcısının çeviri hizmetini bildiği; 16 enformasyon kullanıcısının ise bu enformasyon hizmetini bilmediği görülmektedir.

Tablo III b. Bilgi Kaynaklarının Ödünç Verilmesi

\begin{tabular}{llcccc}
\hline & & Frekans & Yüzde & Geçerli Yüzde & Kümülatif Yüzde \\
\hline Geçerli & Evet & 13 & 44,8 & 48,1 & 48,1 \\
& Hayır & 14 & 48,3 & 51,9 & 100,0 \\
& Toplam & 27 & 93,1 & 100,0 & \\
Dikkate & 2 & 6,9 & & \\
Alınmayan & $\mathbf{2 9}$ & $\mathbf{1 0 0 , 0}$ & & \\
\hline Toplam & & & & \\
\hline
\end{tabular}


Tablo IIIb' de, anketimize cevap veren 27 işletmedeki 13 enformasyon kullanıcısının ödünç verme hizmetini bildiği; 14 enformasyon kullanıcısının ise bu enformasyon hizmetini bilmediği görülmektedir.

Tablo III c. Yöneltme

\begin{tabular}{llcccc}
\hline & & Frekans & Yüzde & Geçerli Yüzde & KümülatifYüzde \\
\hline Geçerli & Evet & 12 & 41,4 & 44,4 & 44,4 \\
& Hayır & 15 & 51,7 & 55,6 & 100,0 \\
& Toplam & 27 & 93,1 & 100,0 & \\
Dikkate & 2 & 6,9 & & \\
Alınmayan & $\mathbf{2 9}$ & $\mathbf{1 0 0 , 0}$ & & \\
\hline Toplam & & & & \\
\hline
\end{tabular}

Tablo IIIc' de, anketimize cevap veren 27 işletmedeki12 enformasyon kullanıcısının yöneltme hizmetini bildiği; 15 enformasyon kullanıcısının ise bu enformasyon hizmetini bilmediği görülmektedir.

Tablo III d. Bilgi Merkezleri Arası Ödünç Verme

\begin{tabular}{llcccc}
\hline & & Frekans & Yüzde & Geçerli Yüzde & Kümülatif Yüzde \\
\hline Geçerli & Evet & 14 & 48,3 & 50,0 & 50,0 \\
& Hayır & 14 & 48,3 & 50,0 & 100,0 \\
& Toplam & 28 & 96,6 & 100,0 & \\
Dikkate & 1 & 3,4 & & \\
Alınmayan & $\mathbf{2 9}$ & $\mathbf{1 0 0 , 0}$ & & \\
\hline Toplam & & & & \\
\hline
\end{tabular}

Tablo IIId' de, anketimize cevap veren 28 işletmedeki 14 enformasyon kullanıcısının bilgi merkezleri arası ödünç verme hizmetini bildiği; 14 enformasyon kullanıcısının ise bu enformasyon hizmetini bilmediği görülmektedir.

Tablo III e. Araştırma ve Geliştirme Hakkında Enformasyon

\begin{tabular}{llcccc}
\hline & & Frekans & Yüzde & Geçerli Yüzde & Kümülatif Yüzde \\
\hline Geçerli & Evet & 26 & 89,7 & 92,9 & 92,9 \\
& Hayır & 2 & 6,9 & 7,1 & 100,0 \\
& Toplam & 28 & 96,6 & 100,0 & \\
Dikkate & 1 & 3,4 & & \\
Alınmayan & $\mathbf{2 9}$ & $\mathbf{1 0 0 , 0}$ & & \\
\hline Toplam & & & & \\
\hline
\end{tabular}


Tablo Ille' de, anketimize cevap veren 28 işletmedeki 26 enformasyon kullanıcısının araştırma ve geliştirme hakkında enformasyon hizmetini bildiği; 2 enformasyon kullanıcısının ise bu enformasyon hizmetini bilmediği görülmektedir.

Tablo III f. Çoğaltma

\begin{tabular}{llcccc}
\hline & & Frekans & Yüzde & Geçerli Yüzde & Kümülatif Yüzde \\
\hline Geçerli & Evet & 17 & 58,6 & 60,7 & 60,7 \\
& Hayır & 11 & 37,9 & 39,3 & 100,0 \\
& Toplam & 28 & 96,6 & 100,0 & \\
Dikkate & 1 & 3,4 & & \\
Alınmayan & $\mathbf{2 9}$ & $\mathbf{1 0 0 , 0}$ & & \\
\hline Toplam & & & & \\
\hline
\end{tabular}

Tablo Illf' de, anketimize cevap veren 28 işletmedeki 17 enformasyon kullanıcısının çoğaltma hizmetini bildiği; 11 enformasyon kullanıcısının ise bu enformasyon hizmetini bilmediği görülmektedir.

Tablo III g. Veri Toplama

\begin{tabular}{clcccc}
\hline & & Frekans & Yüzde & Geçerli Yüzde & Kümülatif Yüzde \\
\hline \multirow{2}{*}{ Geçerli } & Evet & 19 & 65,5 & 65,5 & 65,5 \\
& Hayır & 10 & 34,5 & 34,5 & 100,0 \\
\hline \multirow{2}{*}{ Toplam } & $\mathbf{2 9}$ & $\mathbf{1 0 0 , 0}$ & $\mathbf{1 0 0 , 0}$ & \\
\hline
\end{tabular}

Tablo IIIg' de, anketimize cevap veren 29 işletmedeki 19 enformasyon kullanıcısının veri toplama hizmetini bildiği; 10 enformasyon kullanıcısının ise bu enformasyon hizmetini bilmediği görülmektedir.

Tablo III h. Literatür Taraması

\begin{tabular}{llllll}
\hline & & Frekans & Yüzde & Geçerli Yüzde & Kümülatif Yüzde \\
\hline Geçerli & Evet & 22 & 75,9 & 78,6 & 78,6 \\
& Hayır & 6 & 20,7 & 21,4 & 100,0 \\
& Toplam & 28 & 96,6 & 100,0 & \\
Dikkate & & 3,4 & & \\
Alınmayan & & $\mathbf{2 9}$ & $\mathbf{1 0 0 , 0}$ & & \\
\hline Toplam & & & & \\
\hline
\end{tabular}

Tablo IIlh.'de, anketimize cevap veren 28 işletmedeki 22 enformasyon kullanıcısının literatür taraması hizmetini bildiği; 6 enformasyon kullanıcısının ise bu enformasyon hizmetini bilmediği görülmektedir. 
Tablo III i. Hazır Danışma Hizmeti

\begin{tabular}{llcccc}
\hline & & Frekans & Yüzde & Geçerli Yüzde & Kümülatif Yüzde \\
\hline Geçerli & Evet & 25 & 86,2 & 89,3 & 89,3 \\
& Hayır & 3 & 10,3 & 10,7 & 100,0 \\
& Toplam & 28 & 96,6 & 100,0 & \\
Dikkate & 1 & 3,4 & & \\
Alınmayan & $\mathbf{2 9}$ & $\mathbf{1 0 0 , 0}$ & & \\
\hline Toplam & & &
\end{tabular}

Tablo Illi' de, anketimize cevap veren 28 işletmedeki 25 enformasyon kullanıcısının bhazır danışma hizmetini bildiği; 3 enformasyon kullanıcısının ise bu enformasyon hizmetini bilmediği görülmektedir.

Tablo III j. Patent ve Standart Enformasyonu

\begin{tabular}{llcccc}
\hline & & Frekans & Yüzde & Geçerli Yüzde & Kümülatif Yüzde \\
\hline Geçerli & Evet & 26 & 89,7 & 92,9 & 92,9 \\
& Hayır & 2 & 6,9 & 7,1 & 100,0 \\
& Toplam & 28 & 96,6 & 100,0 & \\
Dikkate & 1 & 3,4 & & \\
Alınmayan & $\mathbf{2 9}$ & $\mathbf{1 0 0 , 0}$ & & \\
\hline Toplam & & & & \\
\hline
\end{tabular}

Tablo IIlj' de, anketimize cevap veren 28 işletmedeki 26 enformasyon kullanıcısının patent ve standart enformasyon hizmetini bildiği; 2 enformasyon kullanıcısının ise bu enformasyon hizmetini bilmediği görülmektedir.

Tablo III k. Yönetim Enformasyonu

\begin{tabular}{llcccc}
\hline & & Frekans & Yüzde & Geçerli Yüzde & Kümülatif Yüzde \\
\hline Geçerli & Evet & 16 & 55,2 & 57,1 & 57,1 \\
& Hayir & 12 & 41,4 & 42,9 & 100,0 \\
& Toplam & 28 & 96,6 & 100,0 & \\
Dikkate & 1 & 3,4 & & \\
Alınmayan & $\mathbf{2 9}$ & $\mathbf{1 0 0 , 0}$ & & \\
\hline Toplam & & & & \\
\hline
\end{tabular}

Tablo IIIk.'de, anketimize cevap veren 28 işletmedeki 16 enformasyon kullanıcısının yönetim enformasyonu hizmetini bildiği; 12 enformasyon kullanıcısının ise bu enformasyon hizmetini bilmediği görülmektedir. 
Tablo III $l$. Diğerleri (belirtiniz)

\begin{tabular}{ccccc}
\hline & Frekans & Yüzde & Geçerli Yüzde & Kümülatif Yüzde \\
\hline Geçerli & 29 & 100,0 & 100,0 & 100,0 \\
\hline
\end{tabular}

Tablo III'de, anketimize cevap veren işletmelerin yukarıdaki enformasyon hizmetlerinden başka herhangi bir enformasyon hizmeti belirtmediği görülmektedir.

Genel olarak şunu diyebiliriz ki, tablolarda da görüldüğü üzere işletmelerdeki enformasyon kullanıcılarının, enformasyon hizmetlerinden en fazla 'araştırma ve geliştirme projeleri hakkında enformasyon' ile 'patent ve standart enformasyonu' konularını bildikleri görülmektedir. Bu alana cevap vermiş olan toplam 28 işletmedeki 26 enformasyon kullanıcısı kullanıcısının ise bu hizmetleri bilmedikleri söylenebilir.

Enformasyon kullanıcılarının daha sonra en çok bildikleri enformasyon hizmetleri sırasıyla 'hazır danışma hizmeti', 'literatür taraması', 'veri toplama' ve 'çoğaltma' hizmetleridir.

Enformasyon kullanıcılarının en az bildikleri enformasyon hizmetleri ise 'bilgi merkezleri arası ödünç verme', 'bilgi kaynaklarının ödünç verilmesi', 'çeviri hizmeti' ve 'yöneltme' hizmetleridir.

KKTC Genel İmalat ve Kâğıt Ürünleri ile Matbaa Sanayisi Işletmelerindeki Enformasyon Kullanıcılarının Gereksinim Duydukları Enformasyon Hizmetleri:

Bu aşamada, genel imalat ve kâğıt ürünleri ile matbaa sanayisi işletmelerindeki enformasyon kullanıcılarının, gereksinim duydukları enformasyon hizmetleri ölçülmeye çalışıımıştır. Ele alınan enformasyon hizmetleri çeviri hizmeti, bilgi kaynaklarının ödünç verilmesi, yöneltme, bilgi merkezleri arası ödünç verme, araştırma ve geliştirme projeleri hakkında enformasyon, çoğaltma, veri toplama, literatür taraması, hazır danışma hizmeti, patent ve standart enformasyonu, yönetim enformasyonu ve diğer enformasyon hizmetleridir. Elde edilen bulgular, aşağıda tablolarla belirtilmektedir.

Tablo IV a. Çeviri Hizmeti

\begin{tabular}{llcccc}
\hline & & Frekans & Yüzde & Geçerli Yüzde & Kümülatif Yüzde \\
\hline Geçerli & Evet & 6 & 20,7 & 22,2 & 22,2 \\
& Hayır & 21 & 72,4 & 77,8 & 100,0 \\
& Toplam & 27 & 93,1 & 100,0 & \\
Dikkate & 2 & 6,9 & & \\
Alınmayan & $\mathbf{2 9}$ & $\mathbf{1 0 0 , 0}$ & & \\
\hline Toplam & & & & \\
\hline
\end{tabular}


Tablo IVa' da, anketimize cevap veren 27 işletmedeki 6 enformasyon kullanıcısının çeviri hizmetine gereksinim duyduğu; 21 enformasyon kullanıcısının ise bu enformasyon hizmetine gereksinim duymadığı görülmektedir.

Tablo IV b. Bilgi Kaynaklarının Ödünç Verilmesi

\begin{tabular}{llcccc}
\hline & & Frekans & Yüzde & Geçerli Yüzde & Kümülatif Yüzde \\
\hline Geçerli & Evet & 6 & 20,7 & 22,2 & 22,2 \\
& Hayır & 21 & 72,4 & 77,8 & 100,0 \\
& Toplam & 27 & 93,1 & 100,0 & \\
Dikkate & 2 & 6,9 & & \\
Alınmayan & $\mathbf{2 9}$ & $\mathbf{1 0 0 , 0}$ & & \\
\hline Toplam & & & & \\
\hline
\end{tabular}

Tablo IVb' de, anketimize cevap veren 27 işletmedeki 6 enformasyon kullanıcısının bilgi kaynaklarının ödünç verilmesi hizmetine gereksinim duyduğu; 21 enformasyon kullanıcısının ise bu enformasyon hizmetine gereksinim duymadığı görülmektedir.

Tablo IV c. Yöneltme

\begin{tabular}{llcccc}
\hline & & Frekans & Yüzde & Geçerli Yüzde & Kümülatif Yüzde \\
\hline Geçerli & Evet & 8 & 27,6 & 29,6 & 29,6 \\
& Hayır & 19 & 65,5 & 70,4 & 100,0 \\
& Toplam & 27 & 93,1 & 100,0 & \\
Dikkate & 2 & 6,9 & & \\
Alınmayan & $\mathbf{2 9}$ & $\mathbf{1 0 0 , 0}$ & & \\
\hline Toplam & & & & \\
\hline
\end{tabular}

Tablo IVc' de, anketimize cevap veren 27 işletmedeki 8 enformasyon kullanıcısının yöneltme hizmetine gereksinim duyduğu; 19 enformasyon kullanıcısının ise bu enformasyon hizmetine gereksinim duymadığı görülmektedir.

Tablo IV d. Bilgi Merkezleri Arası Ödünç Verme

\begin{tabular}{llcccc}
\hline & & Frekans & Yüzde & Geçerli Yüzde & Kümülatif Yüzde \\
\hline Geçerli & Evet & 6 & 20,7 & 22,2 & 22,2 \\
& Hayır & 21 & 72,4 & 77,8 & 100,0 \\
& Toplam & 27 & 93,1 & 100,0 & \\
Dikkate & 2 & 6,9 & & \\
Alınmayan & $\mathbf{2 9}$ & $\mathbf{1 0 0 , 0}$ & & \\
\hline Toplam & & & & \\
\hline
\end{tabular}


Tablo IVd' de, anketimize cevap veren 27 işletmedeki 6 enformasyon kullanıcısının bilgi merkezleri arası ödünç verilme hizmetine gereksinim duyduğu; 21 enformasyon kullanıcısının ise bu enformasyon hizmetine gereksinim duymadığı görülmektedir.

Tablo IV e. Araştırma ve Geliştirme Projeleri Hakkında Enformasyon

\begin{tabular}{llcccc}
\hline & & Frekans & Yüzde & Geçerli Yüzde & Kümülatif Yüzde \\
\hline Geçerli & Evet & 19 & 65,5 & 67,9 & 67,9 \\
& Hayır & 9 & 31,0 & 32,1 & 100,0 \\
& Toplam & 28 & 96,6 & 100,0 & \\
Dikkate & 1 & 3,4 & & \\
Alınmayan & $\mathbf{2 9}$ & $\mathbf{1 0 0 , 0}$ & & \\
\hline Toplam & & & & \\
\hline
\end{tabular}

Tablo IVe' de, anketimize cevap veren 28 işletmedeki 19 enformasyon kullanıcısının araştırma ve geliştirme projeleri hakkında enformasyon hizmetine gereksinim duyduğu; 9 enformasyon kullanıcısının ise bu enformasyon hizmetine gereksinim duymadığı görülmektedir.

Tablo IV f. Çoğaltma

\begin{tabular}{llcccc}
\hline & & Frekans & Yüzde & Geçerli Yüzde & Kümülatif Yüzde \\
\hline Geçerli & Evet & 9 & 31,0 & 33,3 & 33,3 \\
& Hayır & 18 & 62,1 & 66,7 & 100,0 \\
& Toplam & 27 & 93,1 & 100,0 & \\
Dikkate & 2 & 6,9 & & \\
Alınmayan & $\mathbf{2 9}$ & $\mathbf{1 0 0 , 0}$ & & \\
\hline Toplam & & & & \\
\hline
\end{tabular}

Tablo IVf' de, anketimize cevap veren 27 işletmedeki 9 enformasyon kullanıcısının çoğaltma hizmetine gereksinim duyduğu; 18 enformasyon kullanıcısının ise bu enformasyon hizmetine gereksinim duymadığı görülmektedir.

Tablo IV g. Veri Toplama

\begin{tabular}{llcccc}
\hline & & Frekans & Yüzde & Geçerli Yüzde & Kümülatif Yüzde \\
\hline Geçerli & Evet & 14 & 48,3 & 50,0 & 50,0 \\
& Hayır & 14 & 48,3 & 50,0 & 100,0 \\
& Toplam & 28 & 96,6 & 100,0 & \\
Dikkate & 1 & 3,4 & & \\
Alınmayan & $\mathbf{2 9}$ & $\mathbf{1 0 0 , 0}$ & & \\
\hline Toplam & & & & \\
\hline
\end{tabular}


Tablo IVg' de, anketimize cevap veren 28 işletmedeki 14 enformasyon kullanıcısının veri toplama hizmetine gereksinim duyduğu; 14 enformasyon kullanıcısının ise bu enformasyon hizmetine gereksinim duymadığı görülmektedir.

Tablo IV h. Literatür Taraması

\begin{tabular}{llcccc}
\hline & & Frekans & Yüzde & Geçerli Yüzde & Kümülatif Yüzde \\
\hline Geçerli & Evet & 14 & 48,3 & 51,9 & 51,9 \\
& Hayır & 13 & 44,8 & 48,1 & 100,0 \\
& Toplam & 27 & 93,1 & 100,0 & \\
Dikkate & 2 & 6,9 & & \\
Alınmayan & $\mathbf{2 9}$ & $\mathbf{1 0 0 , 0}$ & & \\
\hline Toplam & & & & \\
\hline
\end{tabular}

Tablo IVh' de, anketimize cevap veren 27 işletmedeki 14 enformasyon kullanıcısının literatür taraması hizmetine gereksinim duyduğu; 13 enformasyon kullanıcısının ise bu enformasyon hizmetine gereksinim duymadığı görülmektedir.

Tablo IV i. Hazır Danışma Hizmeti

\begin{tabular}{llcccc}
\hline & & Frekans & Yüzde & Geçerli Yüzde & Kümülatif Yüzde \\
\hline Geçerli & Evet & 21 & 72,4 & 77,8 & 77,8 \\
& Hayır & 6 & 20,7 & 22,2 & 100,0 \\
& Toplam & 27 & 93,1 & 100,0 & \\
Dikkate & 2 & 6,9 & & \\
Alınmayan & $\mathbf{2 9}$ & $\mathbf{1 0 0 , 0}$ & & \\
\hline Toplam & & &
\end{tabular}

Tablo IVi' de, anketimize cevap veren 27 işletmedeki 21 enformasyon kullanıcısının hazır danışma hizmetine gereksinim duyduğu; 6 enformasyon kullanıcısının ise bu enformasyon hizmetine gereksinim duymadığı görülmektedir.

Tablo IV j. Patent ve Standart Enformasyonu

\begin{tabular}{llcccc}
\hline & & Frekans & Yüzde & Geçerli Yüzde & Kümülatif Yüzde \\
\hline Geçerli & Evet & 23 & 79,3 & 85,2 & 85,2 \\
& Hayir & 4 & 13,8 & 14,8 & 100,0 \\
& Toplam & 27 & 93,1 & 100,0 & \\
Dikkate & 2 & 6,9 & & \\
Alınmayan & $\mathbf{2 9}$ & $\mathbf{1 0 0 , 0}$ & & \\
\hline Toplam & & & & \\
\hline
\end{tabular}


Tablo IVj' de, anketimize cevap veren 27 işletmedeki 23 enformasyon kullanıcısının patent ve standart enformasyon hizmetine gereksinim duyduğu; 4 enformasyon kullanıcısının ise bu enformasyon hizmetine gereksinim duymadığı görülmektedir.

Tablo IV k. Yönetim Enformasyonu

\begin{tabular}{lccccc}
\hline & & Frekans & Yüzde & Geçerli Yüzde & Kümülatif Yüzde \\
\hline Geçerli & Evet & 11 & 37,9 & 42,3 & 42,3 \\
& Hayır & 14 & 48,3 & 53,8 & 96,2 \\
& & 1 & 3,4 & 3,8 & 100,0 \\
Dikkate & Toplam & 26 & 89,7 & 100,0 & \\
Alınmayan & 3 & 10,3 & & \\
\hline Toplam & $\mathbf{2 9}$ & $\mathbf{1 0 0 , 0}$ & & \\
\hline
\end{tabular}

Tablo IVk' de, anketimize cevap veren 26 işletmedeki 11 enformasyon kullanıcısının yönetim enformasyonu hizmetine gereksinim duyduğu; 14 enformasyon kullanıcısının ise bu enformasyon hizmetine gereksinim duymadığı görülmektedir.

Tablo IV $l$. Diğerleri (belirtiniz)

\begin{tabular}{ccccc}
\hline & Frekans & Yüzde & Geçerli Yüzde & Kümülatif Yüzde \\
\hline Geçerli & 29 & 100,0 & 100,0 & 100,0 \\
\hline
\end{tabular}

Tablo IV $l^{\prime}$ de anketimize cevap veren işletmelerin, yukarıda belirtilen enformasyon hizmetlerinin dışında ihtiyaç duyduğu herhangi bir hizmet bulunmadığı görülmektedir.

Genel olarak, bu aşamada örneklem grubumuzu oluşturan işletmelerin enformasyon kullanıcılarının gereksinim duydukları enformasyon hizmetleri tespit edilmeye çalışılmıştır.

Tablolarda da görüldüğü üzere genel imalat ve kâğıt ürünleri ile matbaa sanayisi işletmelerindeki enformasyon kullanıcılarının en çok'patent ve standart enformasyonu', 'hazır danışma hizmeti', 'araştırma ve geliştirme projeleri hakkında enformasyon' konularında gereksinim duydukları görülmektedir.

Enformasyon kullanıcılarının daha sonra en çok 'veri toplama', 'literatür taraması' ve 'yönetim enformasyonu' hizmetlerine gereksinim duyduklarl; 'çoğaltma', 'yöneltme', 'çeviri hizmeti', 'bilgi kaynaklarının ödünç verilmesi' ve 'bilgi merkezleri arası ödünç verme' hizmetlerine ise en az düzeyde gereksinim duydukları söylenebilir.

KKTC Genel İmalat ve Kâğıt Ürünleri ile Matbaa Sanayisi İ̧letmelerindeki Enformasyon Kullanıılarının, Herhangi Bir Bilgi Merkezi Kullanmadan da Gereksinilen Enformasyona Erişim Oranı ve Enformasyona Erişimde Nasıl Bir Yol İledikleri: 
Bu aşamada, genel imalat ve kâğıt ürünleri ile matbaa sanayisi işletmelerindeki enformasyon kullanıcılarının, herhangi bir bilgi merkezi kullanmadan gereksinim duydukları enformasyona erişim oranı ve enformasyona erişimde nasıl bir yol izledikleri ölçülmeye çalışılmıştır. Elde edilen bulgular, aşağıda tablolarla belirtilmektedir.

Tablo V a. Herhangi Bir Bilgi Merkezi Kullanmadan Gereksinilen Enformasyona Erişim

\begin{tabular}{llcccc}
\hline & & Frekans & Yüzde & Geçerli Yüzde & Kümülatif Yüzde \\
\hline \multirow{2}{*}{ Geçerli } & Evet & 10 & 34,5 & 34,5 & 34,5 \\
& Hayır & 19 & 65,5 & 65,5 & 100,0 \\
\hline \multirow{2}{*}{ Toplam } & $\mathbf{2 9}$ & $\mathbf{1 0 0 , 0}$ & $\mathbf{1 0 0 , 0}$ & \\
\hline
\end{tabular}

Tablo Va' da görüldüğü üzere, ankete cevap veren 29 işletmedeki 10 enformasyon kullanıcısı, bilgi merkezi kullanmadan gereksinim duydukları enformasyona erişebildiklerini belirtmektedir.

Tablo V b. Ne Tür Bilgilere Nasıl Erişilmektedir?

\begin{tabular}{llcccc}
\hline & Frekans & Yüzde & Geçerli Yüzde & Kümülatif Yüzde \\
\hline Geçerli & 21 & 72,4 & 72,4 & 72,4 \\
& & 5 & 17,2 & 17,2 & 89,7 \\
& Internet & 1 & 3,4 & 3,4 & 93,1 \\
& Internet ve fuarlar & 1 & 3,4 & 3,4 & 96,6 \\
& Internet ve Seminerler & 1 & 3,4 & 3,4 & 100,0 \\
\hline & Online Veritabanları & $\mathbf{2 9}$ & $\mathbf{1 0 0 , 0}$ & $\mathbf{1 0 0 , 0}$ & \\
\hline
\end{tabular}

Tablo $V^{\prime}$ ' de gereksinim duydukları enformasyona bilgi merkezi kullanmadan erişebildiklerini belirten 10 enformasyon kullanıcısının ne tür bilgilere nasıl eriştikleri tespit edilmeye çalışılmıştır. Bu aşamada 8 enformasyon kullanıcısı bu soruya yanıt olarak özellikle internet aracılığı ile enformasyon gereksinimlerini karşıladıklarını belirtmişlerdir. 7 enformasyon kullanıcısı internetten (1 kişi internet + fuarlar, 1 kişi internet + seminerler) enformasyona eriştiklerini belirtirken, 1 enformasyon kullanıcısı ise online veritabanlarından yararlandığını belirtmiştir.

KKTC Genel İmalat ve Kâğıt Ürünleri ile Matbaa Sanayisi Işletmelerinde Araştırma ve Geliştirme Merkezinin Varlığı:

Bu aşamada, genel imalat ve kâğıt ürünleri ile matbaa sanayisi işletmelerinde, araştırma ve geliştirme merkezinin varlığı tespit edilmeye çalışıımıştır. 
Tablo VI. Araştırma ve Geliştirme Merkezinin Varlığı

\begin{tabular}{clcccc}
\hline & & Frekans & Yüzde & Geçerli Yüzde & Kümülatif Yüzde \\
\hline \multirow{2}{*}{ Geçerli } & Evet & 3 & 10,3 & 10,3 & 10,3 \\
& Hayır & 26 & 89,7 & 89,7 & 100,0 \\
\hline \multirow{2}{*}{ Toplam } & $\mathbf{2 9}$ & $\mathbf{1 0 0 , 0}$ & $\mathbf{1 0 0 , 0}$ & \\
\hline
\end{tabular}

Tablo Vl' da görülmektedir ki, ankete cevap veren toplam 29 genel imalat ve kâğıt ürünleri ile matbaa sanayisi işletmelerinin 3 'ünde araştırma ve geliştirme merkezi bulunmakta, diğer 26 işletmede ise araştırma ve geliştirme merkezi bulunmamaktadır.

KKTC Genel Imalat ve Kâğıt Ürünleri ile Matbaa Sanayisi Işletmelerinin ihracat Durumu:

Bu aşamada, genel imalat ve kâğıt ürünleri ile matbaa sanayisi işletmelerinin ihracat yapma durumu tespit edilmeye çalışılmıştır.

Tablo VII. ihracat Durumu

\begin{tabular}{clcccc}
\hline \multirow{2}{*}{ Geçerli } & & Frekans & Yüzde & Geçerli Yüzde & Kümülatif Yüzde \\
\cline { 2 - 6 } & Evet & 3 & 10,3 & 10,3 & 10,3 \\
& Hayır & 26 & 89,7 & 89,7 & 100,0 \\
\hline \multirow{2}{*}{ Toplam } & $\mathbf{2 9}$ & $\mathbf{1 0 0 , 0}$ & $\mathbf{1 0 0 , 0}$ & \\
\hline
\end{tabular}

Tablo VII. incelendiğinde görülmektedir ki, araştırmaya katılan 29 sanayi işletmesinden yalnızca 3'ü ihracat yapmaktadır.

KKTC Genel Imalat ve Kâğıt Ürünleri ie Matbaa Sanayisi İ̧letmelerinin Enformasyon Gereksinimleri:

Bu aşamada, genel imalat ve kâğıt ürünleri ile matbaa sanayisi işletmelerinin insan gücüne, hammaddeye, finansmana, standartlara, çalışma yerine, donatıma, mevzuata, teknolojiye, yönetime, çevre korumaya, pazarlamaya ve diğerlerine ilişkin enformasyon gereksinimleri ölçülmeye çalışılmıştır. Elde edilen bulgular, aşağıda tablolarla belirtilmektedir.

Tablo VIII a. İnsan Gücüne Illişkin Enformasyon

\begin{tabular}{clcccc}
\hline \multirow{2}{*}{ Geçerli } & & Frekans & Yüzde & Geçerli Yüzde & Kümülatif Yüzde \\
\cline { 2 - 5 } & Hayıt & 27 & 93,1 & 93,1 & 93,1 \\
& Toplam & $\mathbf{2 9}$ & $\mathbf{1 0 0 , 0}$ & $\mathbf{1 0 0 , 0}$ & 100,0 \\
\hline
\end{tabular}

Tablo VIIla' da, anketimize cevap veren 29 işletmedeki27 enformasyon kullanıcısının insan gücüne ilişkin enformasyona gereksinim duyduğu; 2 enformasyon kullanııısının ise bu enformasyona gereksinim duymadığı görülmektedir. 
Tablo VIII b. Hammaddeye İlişkin Enformasyon

\begin{tabular}{llcccc}
\hline & & Frekans & Yüzde & Geçerli Yüzde & Kümülatif Yüzde \\
\hline \multirow{2}{*}{ Geçerli } & Evet & 26 & 89,7 & 89,7 & 89,7 \\
& Hayır & 3 & 10,3 & 10,3 & 100,0 \\
\hline & Toplam & $\mathbf{2 9}$ & $\mathbf{1 0 0 , 0}$ & $\mathbf{1 0 0 , 0}$ & \\
\hline
\end{tabular}

Tablo VIIIb' de, anketimize cevap veren 29 işletmedeki 26 enformasyon kullanıcısının hammaddeye ilişkin enformasyona gereksinim duyduğu; 3 enformasyon kullanıcısının ise bu enformasyona gereksinim duymadığı görülmektedir.

Tablo VIII c. Finansmana İlişkin Enformasyon

\begin{tabular}{llcccc}
\hline & & Frekans & Yüzde & Geçerli Yüzde & Kümülatif Yüzde \\
\hline \multirow{2}{*}{ Valid } & Evet & 24 & 82,8 & 82,8 & 82,8 \\
& Hayır & 5 & 17,2 & 17,2 & 100,0 \\
\hline & Toplam & $\mathbf{2 9}$ & $\mathbf{1 0 0 , 0}$ & $\mathbf{1 0 0 , 0}$ & \\
\hline
\end{tabular}

Tablo VIIIc' de, anketimize cevap veren 29 işletmedeki 24 enformasyon kullanıcısının finansmana ilişkin enformasyona gereksinim duyduğu; 5 enformasyon kullanıcısının ise bu enformasyona gereksinim duymadığı görülmektedir.

Tablo VIII d. Standartlara İlişkin Enformasyon

\begin{tabular}{llcccc}
\hline & & Frekans & Yüzde & Geçerli Yüzde & Kümülatif Yüzde \\
\hline Geçerli & Evet & 18 & 62,1 & 64,3 & 64,3 \\
& Hayır & 10 & 34,5 & 35,7 & 100,0 \\
& Toplam & 28 & 96,6 & 100,0 & \\
Dikkate & 1 & 3,4 & & \\
Alınmayan & $\mathbf{2 9}$ & $\mathbf{1 0 0 , 0}$ & & \\
\hline Toplam & & & & \\
\hline
\end{tabular}

Tablo VIIId' de, anketimize cevap veren 28 işletmedeki 18 enformasyon kullanıcısının standartlara ilişkin enformasyona gereksinim duyduğu; 10 enformasyon kullanıcısının ise bu enformasyona gereksinim duymadığı görülmektedir. 
Tablo VIII e. Çalışma Yerine ilişskin Enformasyon

\begin{tabular}{llcccc}
\hline & & Frekans & Yüzde & Geçerli Yüzde & Kümülatif Yüzde \\
\hline Geçerli & Evet & 20 & 69,0 & 74,1 & 74,1 \\
& Hayır & 7 & 24,1 & 25,9 & 100,0 \\
& Toplam & 27 & 93,1 & 100,0 & \\
Dikkate & 2 & 6,9 & & \\
Alınmayan & $\mathbf{2 9}$ & $\mathbf{1 0 0 , 0}$ & & \\
\hline Toplam & & & & \\
\hline
\end{tabular}

Tablo VIIle' de, anketimize cevap veren 27 işletmedeki 20 enformasyon kullanıcısının çalışma yerine ilişkin enformasyona gereksinim duyduğu; 7 enformasyon kullanıcısının ise bu enformasyona gereksinim duymadığı görülmektedir.

Tablo VIII f. Donatıma İlişkin Enformasyon

\begin{tabular}{llcccc}
\hline & & Frekans & Yüzde & Geçerli Yüzde & Kümülatif Yüzde \\
\hline Geçerli & Evet & 17 & 58,6 & 65,4 & 65,4 \\
& Hayır & 9 & 31,0 & 34,6 & 100,0 \\
& Toplam & 26 & 89,7 & 100,0 & \\
Dikkate & 3 & 10,3 & & \\
Alınmayan & $\mathbf{2 9}$ & $\mathbf{1 0 0 , 0}$ & & \\
\hline Toplam & & & & \\
\hline
\end{tabular}

Tablo VIIIf' de, anketimize cevap veren 26 işletmedeki 17 enformasyon kullanıcısının donatıma ilişkin enformasyona gereksinim duyduğu; 9 enformasyon kullanıcısının ise bu enformasyona gereksinim duymadığı görülmektedir.

Tablo VIII g. Mevzuata Illişkin Enformasyon

\begin{tabular}{llcccc}
\hline & & Frekans & Yüzde & Geçerli Yüzde & Kümülatif Yüzde \\
\hline Geçerli & Evet & 21 & 72,4 & 75,0 & 75,0 \\
& Hayır & 7 & 24,1 & 25,0 & 100,0 \\
& Toplam & 28 & 96,6 & 100,0 & \\
Dikkate & 1 & 3,4 & & \\
Alınmayan & $\mathbf{2 9}$ & $\mathbf{1 0 0 , 0}$ & & \\
\hline Toplam & & &
\end{tabular}

Tablo VIIIg' de, anketimize cevap veren 28 işletmedeki 21 enformasyon kullanıcısının mevzuata ilişkin enformasyona gereksinim duyduğu; 7 enformasyon kullanıcısının ise bu enformasyona gereksinim duymadığı görülmektedir. 
Tablo VIII h. Teknolojiye İlişkin Enformasyon

\begin{tabular}{llcccc}
\hline & & Frekans & Yüzde & Geçerli Yüzde & Kümülatif Yüzde \\
\hline \multirow{2}{*}{ Geçerli } & Evet & 27 & 93,1 & 93,1 & 93,1 \\
& Hayır & 2 & 6,9 & 6,9 & 100,0 \\
\hline & Toplam & $\mathbf{2 9}$ & $\mathbf{1 0 0 , 0}$ & $\mathbf{1 0 0 , 0}$ & \\
\hline
\end{tabular}

Tablo VIIIh' de, anketimize cevap veren 29 işletmedeki 27 enformasyon kullanıcısının teknolojiye ilişkin enformasyona gereksinim duyduğu; 2 enformasyon kullanıcısının ise bu enformasyona gereksinim duymadığı görülmektedir.

Tablo VIII i. Yönetime İlişkin Enformasyon

\begin{tabular}{llcccc}
\hline & & Frekans & Yüzde & Geçerli Yüzde & Kümülatif Yüzde \\
\hline Geçerli & Evet & 19 & 65,5 & 67,9 & 67,9 \\
& Hayır & 9 & 31,0 & 32,1 & 100,0 \\
& Toplam & 28 & 96,6 & 100,0 & \\
Dikkate & 1 & 3,4 & & \\
Alınmayan & $\mathbf{2 9}$ & $\mathbf{1 0 0 , 0}$ & & \\
\hline Toplam & & &
\end{tabular}

Tablo VIIli' de, anketimize cevap veren 28 işletmedeki 19 enformasyon kullanıcısının yönetime ilişkin enformasyona gereksinim duyduğu; 9 enformasyon kullanıcısının ise bu enformasyona gereksinim duymadığı görülmektedir.

Tablo VIII j. Çevre Korumaya İlişkin Enformasyon

\begin{tabular}{llcccc}
\hline & & Frekans & Yüzde & Geçerli Yüzde & Kümülatif Yüzde \\
\hline Geçerli & Evet & 20 & 69,0 & 71,4 & 71,4 \\
& Hayır & 8 & 27,6 & 28,6 & 100,0 \\
& Toplam & 28 & 96,6 & 100,0 & \\
Dikkate & 1 & 3,4 & & \\
Alınmayan & $\mathbf{2 9}$ & $\mathbf{1 0 0 , 0}$ & & \\
\hline Toplam & & &
\end{tabular}

Tablo VIIIj' de, anketimize cevap veren 28 işletmedeki 20 enformasyon kullanıcısının çevre korumaya ilişkin enformasyona gereksinim duyduğu; 8 enformasyon kullanıcısının ise bu enformasyona gereksinim duymadığı görülmektedir. 
Tablo VIII k. Pazarlamaya Illişkin Enformasyon

\begin{tabular}{llcccc}
\hline & & Frekans & Yüzde & Geçerli Yüzde & Kümülatif Yüzde \\
\hline Geçerli & Evet & 27 & 93,1 & 96,4 & 96,4 \\
& Hayır & 1 & 3,4 & 3,6 & 100,0 \\
& Toplam & 28 & 96,6 & 100,0 & \\
Dikkate & 1 & 3,4 & & \\
Alınmayan & $\mathbf{2 9}$ & $\mathbf{1 0 0 , 0}$ & & \\
\hline Toplam & & & & \\
\hline
\end{tabular}

Tablo VIIIk' de, anketimize cevap veren 28 işletmedeki 27 enformasyon kullanıcısının pazarlamaya ilişkin enformasyona gereksinim duyduğu; 1 enformasyon kullanıcısının ise bu enformasyona gereksinim duymadığı görülmektedir.

Tablo VIII $l$. Diğerlerine Ilişkin Enformasyon

\begin{tabular}{lllll}
\hline & Frekans & Yüzde & Geçerli Yüzde & Kümülatif Yüzde \\
\hline Geçerli & 29 & 100,0 & 100,0 & 100,0 \\
\hline
\end{tabular}

Tablo VIIIb' de, anketimize cevap veren işletmelerin yukarıda belirtilen enformasyon gereksinimleri dışında herhangi bir şey belirtmedikleri görülmektedir.

Genel olarak şunu diyebiliriz ki, genel imalat ve kâğıt ürünleri ile matbaa sanayisi işletmelerinin enformasyon kullanıcılarının gereksinim duyduğu enformasyon konuları sırasıyla insan gücü - teknoloji - pazarlama, hammadde, finansman, mevzuat, çalışma yeri - çevre koruma, yönetim, standart ve donatımdır.

KKTC Genel İmalat ve Kâğıt Ürünleri ile Matbaa Sanayisi Işletmelerinde Enformasyona Gereksinim Duyan Bireyler:

Bu aşamada, genel imalat ve kâğıt ürünleri ile matbaa sanayisi işletmelerinde enformasyona gereksinim duyan bireyler tespit edilmeye çalışı ımıstır.

Tablo IX. Enformasyona Gereksinim Duyan Bireyler

\begin{tabular}{llcccc}
\hline & Frekans & Yüzde & Geçerli Yüzde & Kümülatif Yüzde \\
\hline Geçerli & İş Görenler & 4 & 13,8 & 13,8 & 13,8 \\
& $\begin{array}{l}\text { İş Verenler } \\
\text { Orta Düzey Yöneticiler }\end{array}$ & 8 & 27,6 & 27,6 & 41,4 \\
& Üst Düzey Yöneticiler & 3 & 10,3 & 10,3 & 51,7 \\
Hepsi & 14 & 48,3 & 48,3 & 100,0 \\
\hline & Toplam & $\mathbf{2 9}$ & $\mathbf{1 0 0 , 0}$ & $\mathbf{1 0 0 , 0}$ & \\
\hline
\end{tabular}


Tablo IX' da da görüldüğü üzere genel imalat ve kâğıt ürünleri ile matbaa sanayisi işletmelerinde enformasyona en çok gereksinim duyan bireylerin belirlenmeye çalışıldığı bu kısımda çoğunluk "Herkes" yanıtını vermiştir. Çalışmaya katılmış 29 işletmeden 14'ü 'hepsi' seçeneğini işaretlemiştir. Daha sonra sırasıyla enformasyona gereksinim duyan bireyler işverenler, iş görenler ve üst düzey yöneticiler olarak belirlenmiştir.

\section{Ulusal Endüstri Enformasyon Merkezine Gereksinim Duyma Durumu:}

Bu aşamada, ulusal endüstri enformasyon merkezine gereksinim duyma durumu tespit edilmeye çalışılmıştır.

Tablo X. Ulusal Endüstri Enformasyon Merkezine Gereksinim Duyma Durumu

\begin{tabular}{llcccc}
\hline & & Frekans & Yüzde & Geçerli Yüzde & Kümülatif Yüzde \\
\hline Geçerli & Evet & 17 & 58,6 & 60,7 & 60,7 \\
& Hayır & 11 & 37,9 & 39,3 & 100,0 \\
& Toplam & 28 & 96,6 & 100,0 & \\
Dikkate & 1 & 3,4 & & \\
Alınmayan & $\mathbf{2 9}$ & $\mathbf{1 0 0 , 0}$ & & \\
\hline Toplam & & & & \\
\hline
\end{tabular}

Tablo $X^{\prime}$ da görüldüğü üzere genel imalat ve kâğıt ürünleri ile matbaa sanayisi işletmelerinin enformasyon kullanıcılarının 17'si, Kıbrıs Türk sanayisinin enformasyon gereksinimlerini karşılamak üzere bir ulusal merkezin kurulması gerektiğini belirtmişlerdir.

Anket formları incelendiği zaman, ulusal bir endüstri enformasyon merkezinin kurulmasını isteyen enformasyon kullanıcılarının, böyle bir merkezin kurulmasını, KKTC'nin sanayi sektöründe gelişmesi, kalkınması ve daha iyi bir ekonomiye sahip olması için istedikleri görülmektedir. Yatırımcıların yatırım yapacakları alanlarla ilgili enformasyona ulaşması, sanayicilerin kendilerini geliştirmesi ve dünyadaki gelişmeleri (örneğin teknolojik, finansal, yasal düzenlemeler) takip etmesi, standartlara uygun üretim ve ihracat yapabilmeleri için gereksinim duydukları enformasyonun karşılanması adına böyle bir merkezin kurulmasının çok faydalı olacağını belirtmişlerdir.

KKTC Genel İmalat ve Kâğıt Ürünleri ile Matbaa Sanayisi Işletmelerinin Gereksinim Duyduğu Doküman ve/veya Enformasyon Kaynakları:

Bu aşamada, genel imalat ve kâğıt ürünleri ile matbaa sanayisi işletmelerinin gereksinim duyduğu doküman ve/veya enformasyon kaynakları tespit edilmeye ve gereksinim düzeyleri ölçülmeye çalışılmıştır. 
Tablo XI a. Rehberlere Yönelik Doküman ve/veya Enformasyon Kaynaklarına İlişkin Gereksinim Düzeyi

\begin{tabular}{llcccc}
\hline & & Frekans & Yüzde & Geçerli Yüzde & Kümülatif Yüzde \\
\hline Geçerli & Evet & 27 & 93,1 & 96,4 & 96,4 \\
& Hayır & 1 & 3,4 & 3,6 & 100,0 \\
& Toplam & 28 & 96,6 & 100,0 & \\
Dikkate Alınmayan & & 1 & 3,4 & & \\
\hline Toplam & $\mathbf{2 9}$ & $\mathbf{1 0 0 , 0}$ & & & \\
\hline
\end{tabular}

Tablo Xla' da, anketimize cevap veren 28 işletmedeki 27 enformasyon kullanıcısının rehberlere yönelik doküman ve/veya enformasyon kaynaklarına gereksinim duyduğu; 1 enformasyon kullanıcısının ise bu enformasyon kaynaklarına gereksinim duymadığı görülmektedir.

Tablo XI b. Güncel Literatüre Yönelik Doküman ve/veya Enformasyon Kaynaklarına İlişkin Gereksinim Düzeyi

\begin{tabular}{llcccc}
\hline & & Frekans & Yüzde & Geçerli Yüzde & Kümülatif Yüzde \\
\hline \multirow{2}{*}{ Geçerli } & Evet & 22 & 75,9 & 88,0 & 88,0 \\
& Hayır & 3 & 10,3 & 12,0 & 100,0 \\
& Toplam & 25 & 86,2 & 100,0 & \\
Dikkate Alınmayan & 4 & 13,8 & & \\
\hline
\end{tabular}

\begin{tabular}{lll}
\hline Toplam & 29 & 100,0
\end{tabular}

Tablo XIb' de, anketimize cevap veren 25 işletmedeki 22 enformasyon kullanıcısının güncel literatüre yönelik doküman ve/veya enformasyon kaynaklarına gereksinim duyduğu; 3 enformasyon kullanıcısının ise bu enformasyon kaynaklarına gereksinim duymadığı görülmektedir.

Tablo XI c. Patentler ve Standartlara Yönelik Doküman ve/veya Enformasyon Kaynaklarına İlişkin Gereksinim Düzeyi

\begin{tabular}{llcccc}
\hline & & Frekans & Yüzde & Geçerli Yüzde & Kümülatif Yüzde \\
\hline Geçerli & Evet & 22 & 75,9 & 84,6 & 84,6 \\
& Hayır & 4 & 13,8 & 15,4 & 100,0 \\
& Toplam & 26 & 89,7 & 100,0 & \\
Dikkate & 3 & 10,3 & & \\
Alınmayan & $\mathbf{2 9}$ & $\mathbf{1 0 0 , 0}$ & & \\
\hline Toplam & & &
\end{tabular}


Tablo XIc' de, anketimize cevap veren 26 işletmedeki 22 enformasyon kullanıcısının patentler ve standartlara yönelik doküman ve/veya enformasyon kaynaklarına gereksinim duyduğu; 4 enformasyon kullanıcısının ise bu enformasyon kaynaklarına gereksinim duymadığı görülmektedir.

Tablo XI d. Gelecekte Yapılacak Toplantılar ve Sergilerle Yönelik Doküman ve/veya Enformasyon Kaynaklarına İlişkin Gereksinim Düzeyi

\begin{tabular}{llcccc}
\hline & & Frekans & Yüzde & Geçerli Yüzde & Kümülatif Yüzde \\
\hline Geçerli & Evet & 26 & 89,7 & 96,3 & 96,3 \\
& Hayır & 1 & 3,4 & 3,7 & 100,0 \\
& Toplam & 27 & 93,1 & 100,0 & \\
Dikkate & 2 & 6,9 & & \\
Alınmayan & $\mathbf{2 9}$ & $\mathbf{1 0 0 , 0}$ & & \\
\hline Toplam & & & & \\
\hline
\end{tabular}

Tablo XId' de, anketimize cevap veren 27 işletmedeki 26 enformasyon kullanıcısının gelecekte yapılacak toplantılar ve sergilere yönelik doküman ve/veya enformasyon kaynaklarına gereksinim duyduğu; 1 enformasyon kullanıcısının ise bu enformasyon kaynaklarına gereksinim duymadığı görülmektedir.

Tablo XI e. Monograflara Yönelik Doküman ve/veya Enformasyon Kaynaklarına Iliş̧kin Gereksinim Düzeyi

\begin{tabular}{llcccc}
\hline & & Frekans & Yüzde & Geçerli Yüzde & Kümülatif Yüzde \\
\hline Geçerli & Evet & 16 & 55,2 & 59,3 & 59,3 \\
& Hayır & 11 & 37,9 & 40,7 & 100,0 \\
& Toplam & 27 & 93,1 & 100,0 & \\
Dikkate Alınmayan & 2 & 6,9 & & \\
\hline Toplam & $\mathbf{2 9}$ & $\mathbf{1 0 0 , 0}$ & & \\
\hline
\end{tabular}

Tablo Xle' de, anketimize cevap veren 27 işletmedeki 16 enformasyon kullanıcısının monograflara yönelik doküman ve/veya enformasyon kaynaklarına gereksinim duyduğu; 11 enformasyon kullanıcısının ise bu enformasyon kaynaklarına gereksinim duymadığı görülmektedir. 
Tablo XI f. Kesik Koleksiyona Yönelik Doküman ve/veya Enformasyon Kaynaklarına İlişkin Gereksinim Düzeyi

\begin{tabular}{llcccc}
\hline & & Frekans & Yüzde & Geçerli Yüzde & Kümülatif Yüzde \\
\hline Geçerli & Evet & 16 & 55,2 & 64,0 & 64,0 \\
& Hayır & 9 & 31,0 & 36,0 & 100,0 \\
& Toplam & 25 & 86,2 & 100,0 & \\
Dikkate Alınmayan & 4 & 13,8 & & \\
\hline \multicolumn{2}{l}{ Toplam } & $\mathbf{2 9}$ & $\mathbf{1 0 0 , 0}$ & & \\
\hline
\end{tabular}

Tablo XIf' de, anketimize cevap veren 25 işletmedeki 16 enformasyon kullanıcısının kesik koleksiyona yönelik doküman ve/veya enformasyon kaynaklarına gereksinim duyduğu; 9 enformasyon kullanıcısının ise bu enformasyon kaynaklarına gereksinim duymadığı görülmektedir.

Tablo XI g. Yasal Bilgiye Yönelik Doküman ve/veya Enformasyon Kaynaklarına Ilişkin Gereksinim Düzeyi

\begin{tabular}{|c|c|c|c|c|c|}
\hline & & Frekans & Yüzde & Geçerli Yüzde & Kümülatif Yüzde \\
\hline Geçerli & Evet & 27 & 93,1 & 100,0 & 100,0 \\
\hline \multicolumn{2}{|c|}{ Dikkate Alınmayan } & 2 & 6,9 & & \\
\hline \multicolumn{2}{|l|}{ Toplam } & 29 & 100,0 & & \\
\hline
\end{tabular}

Tablo XIg' de, anketimize cevap veren 29 işletmedeki 27 enformasyon kullanıcısının yasal bilgiye yönelik doküman ve/veya enformasyon kaynaklarına gereksinim duyduğu; 2 enformasyon kullanıcısının ise bu enformasyon kaynaklarına gereksinim duymadığı görülmektedir.

Tablo XI h. Pazarlamaya Yönelik Doküman ve/veya Enformasyon Kaynaklarına Ilişkin Gereksinim Düzeyi

\begin{tabular}{llcccc}
\hline & & Frekans & Yüzde & Geçerli Yüzde & Kümülatif Yüzde \\
\hline \multirow{2}{*}{ Geçerli } & Evet & 22 & 75,9 & 81,5 & 81,5 \\
& Hayır & 5 & 17,2 & 18,5 & 100,0 \\
& Toplam & 27 & 93,1 & 100,0 & \\
Dikkate Alınmayan & 2 & 6,9 & & \\
\hline Toplam & $\mathbf{2 9}$ & $\mathbf{1 0 0 , 0}$ & & \\
\hline
\end{tabular}

Tablo XIh' de, anketimize cevap veren 27 işletmedeki 22 enformasyon kullanıcısının pazarlamaya yönelik doküman ve/veya enformasyon kaynaklarına gereksinim duyduğu; 5 enformasyon kullanıcısının ise bu enformasyon kaynaklarına gereksinim duymadığı görülmektedir. 
Tablo XI i. Diğerlerine Yönelik Doküman ve/veya Enformasyon Kaynaklarına İlişkin Gereksinim Düzeyi

\begin{tabular}{ccccc}
\hline & Frekans & Yüzde & Geçerli Yüzde & Kümülatif Yüzde \\
\hline Geçerli & 29 & 100,0 & 100,0 & 100,0 \\
\hline
\end{tabular}

Tablo Xli' de, anketimize cevap veren işletmelerin belirtilen doküman ve/veya enformasyon kaynakları dışında gereksinim duydukları herhangi bir kaynağın olmadığı görülmektedir.

Genel olarak yukarıdaki tablolar incelendiği zaman görülmektedir ki genel imalat ve kâğıt ürünleri ile matbaa sanayisi işletmelerinin en çok gereksinim duyduğu doküman ve / veya enformasyon kaynağı bu alanlara ilişkin rehber ve yasal enformasyondur. Daha sonra en çok gereksinim duyulan doküman ve/veya enformasyon kaynağı gelecekte yapılacak toplantılar ve sergilerdir. Bu doküman ve enformasyon kaynaklarından sonra sırayla gereksinim duyulan doküman ve/veya bilgi kaynakları güncel genel imalat / kâğıt ürünleri ile matbaa sanayi literatürü - patentler ve standartlar - pazarlama enformasyonu, monograflar ve kesik koleksiyondur.

\section{Sonuç}

Kuzey Kıbrıs Türk Cumhuriyeti'nde sanayi sektöründeki işletmelerin temel sorunlarına bakıldığında bunların başında finansman, hammadde tedariki, pazarlama, kalite kontrol bilincinin yeterince yerleşmemiş olması ve teknoloji gibi unsurların en başta gelmekte olduğu görülmektedir.

Yukarıda belirtilen alanlarda yaşanan sıkıntıların yanı sıra Kuzey Kıbrıs'taki işletmelerin ihracata yönelmesini güçleştiren unsurlarında olduğu görülmektedir. $\mathrm{Bu}$ unsurlar arasında maliyet, verimsiz üretim ve verimsiz üretime paralel olarak standartlara uygun kaliteli ürünlerin üretilmemesi gelmektedir. Üretilen ürünlerin standartlara uygun olmaması işletmelerin dış pazarda rekabet edememelerine sebep olmakta ve kalite sorunlarını beraberinden getirmektedir.

Özellikle KKTC'nin dünya ülkelerince tanınmamış olması en büyük ihracat sorununu oluşturmakta ve buna bağlı olarak dış pazar yeterince takip edilememekte ve ulaşımda bir dizi güçlüklerle karşılaşılmaktadır.

İmalat sanayinin sağlıklı bir şekilde gelişebilmesi için, KKTC Devlet Planlama Örgütü'nden de elde edilen bilgilere göre, enerji alanında yaşanan sorunların tamamen çözülmesi gerekmektedir. Diğer yandan ulaşımdan kaynaklanan sorunlar da imalat sanayi sektörünün gelişmesini olumsuz şekilde etkilemektedir. Ulaşımda özellikle hava ve deniz yollarının ihtiyaçları karşılayacak bir düzeye getirilmesi, ürünlerin dış pazarlarda kolaylıkla ve ucuza ulaştırılması imkânını sağlayacaktır. 
Bu bağlamda diyebiliriz ki KKTC'nin enerji, ulaşım, haberleşme sektörlerinin gelişmesi sanayi sektörünün de önünü açacaktır.

KKTC'deki girişimcilerin, rekabet gücünü ve verimliliğini artıracak politikalara ihtiyaçları vardır ve girişimcilik faaliyetlerinin desteklenmesi gerekmektedir.

Bu çalışmada KKTC'deki ekonomik durumu, sanayi sektörünün gelişimini ve bugün ki şeklini ele alırken örneklem grubunu oluşturan sanayi işletmelerinin, bir sanayi işletmesinin temeli olan endüstriyel enformasyona olan farkındalık düzeyleri ile endüstriyel enformasyona olan gereksinim düzeyleri belirlenmeye çalışılmıştır.

Çalışma sonucunda görülmektedir ki, çalışma grubunu oluşturan işletmelerin \% $82,8^{\prime}$ inde, bir işletmede bilgi akış sürecini sağlayan ve enformasyon kullanıcılarına gereksinim duydukları enformasyon hizmetlerini sunan bilgi merkezlerinin varlığı söz konusu değildir. Oysa bilgi merkezi dediğimiz sistem, enformasyon ile enformasyon kullanıcısını buluşturan önemli bir mekanizmadır.

KKTC'nin coğrafik durumu ele alındığı zaman ulusal bir endüstri enformasyon merkezinin kurulması hayal değildir. Sanayi sektörüne yönelik bir bilgi merkezinin kurulması, ülkede sanayi alanında yaşanan sorunların azalmasına ve zamanla ortadan kalkmasına yardımcı olacaktır. Yukarıda belirtilen sanayi sektöründeki temel sorunlar olan finansman, hammadde tedariki, pazarlama, kalite kontrol bilincinin yeterince yerleşmemiş olması, teknoloji gibi unsurlar genel anlamda KKTC'deki bütün sanayi kuruluşlarının temel sorunudur. Çalışma grubunu oluşturan işletmelerin \% $\% 6,6$ ' sı da böyle bir ulusal merkezin oluşmasına gereksinim duyduklarını belirtmişlerdir.

Çalışma kapsamında yer alan tablolarda görülmektedir ki KKTC'deki genel imalat ve kâğıt ürünleri ile matbaa sanayisi işletmeleri üretim sürecinde, $\% 93,1$ insan gücüne, pazarlama teknolojiye ilişkin enformasyona, $\% 89,7$ hammaddeye ilişkin enformasyona, $\% 82,8$ finansmana ilişkin enformasyona, \% 72,4 mevzuata ilişkin enformasyona, \% 69,0 çalışma yeri ile çevre korumaya ilişkin enformasyona, \% 65,5 yönetime ilişkin enformasyona, \% 62,1 standartlara ilişkin enformasyon ve \% 58,6 donatıma ilişkin enformasyona gereksinim duymaktadır. Daha etkin ve verimli üretim için işletmelerin bu alanlardaki gereksinimlerinin en üst düzeyde karşılanması gerekmektedir.

KKTC'de sanayi sektörünün gelişimini engelleyen unsurlar ve 1974 sonrasında yaşanan kayıplar çalışma kapsamında belirtilmiştir. Yaşanan bu kayıpların temelinde enformasyon eksikliği ve yetersizliği yatmaktadır. Enformasyonun doğru ve zamanında kullanılması, daha güçlü bir ekonomik yapı ve yüksek refah düzeyine sahip bir toplum açısından önemlidir.

Aslında bugün KKTC'de ihracat yapılamaması ve dış pazarda rekabet edilememesinin temelinde de endüstriyel enformasyonun eksikliği bulunmaktadır. Bu bağlamda enerji, ulaştırma ve haberleşme alanlarında endüstriyel enformasyona ve çözümleyici bilgi politikalarına ihtiyaç vardır. 
Bugün yaşadığımız toplumsal dönüşüme adını veren 'enformasyon'daki devrimdir ve bu dönüşüm daha öncede belirtildiği gibi bilgi ve/veya enformasyon çağı olarak adlandırılmaktadır. Yaşadığımız çağda enformasyon toplumu olabilmek için her konuda enformasyonun bir gereksinim olduğu bilincine varmak ve endüstri sektöründe endüstriyel enformasyona olan farkındalık düzeyimizi artırmamız gerekmektedir.

\section{Kaynakça}

Arda, E. (2002). Ekonomi sözlüğü (1. bs.). İstanbul: ALFA.

Ataman, B. K. (1995). Arşivcilik terimleri sözlüğü (2. bs.). İstanbul: AREM.

Devlet Planlama Örgütü. (2010). 2008 yılı makroekonomik ve sektörel gelişmeler. Lefkoşa: KKTC Devler Planlama Örgütü İzleme ve Koordinasyon Dairesi.

Eurostat (2011). 15 Eylül 2011 tarihinde http://epp.eurostat.ec.europa.eu adresinden erişildi.

Gürdal, O. (2000). Tekstil endüstrisinde enformasyon olgusu (1. bs.). Ankara: Türk Kütüphaneciler Derneği.

Gürdal, O. (1991). Endüstriyel enformasyon ve Türkiye. 1991 Sanayi Kongresi Bildiriler Kitabı içinde (ss. 103-112). Ankara: Türkiye Mimarlar ve Mühendisler Odası Birliği Makina Mühendisleri Odası. 10 Eylül 2011 tarihinde http://arsiv.mmo.org.tr/pdf/10673.pdf adresinden erişildi.

Hançerlioğlu, O. (2004). Ekonomi sözlüğü (9. bs.). Ankara: Remzi Kitabevi.

İskeçeli, M. (1971). Enformasyon bilimi. Türk Kütüphaneciler Derneği Bülteni, 20(2), 93-96. 10 Eylül 2011 tarihinde http://tk.kutuphaneci.org.tr/index.php/tk/article/viewFile/578/1155 adresinden erişildi.

Kıbrıs Türk Yatırım ve Geliştirme Ajansı. (2011). 12 Eylül 2011 tarihinde http://www. investinnorthcyprus.org adresinden erişildi.

KKTC Merkez Bankası. (2011). 12 Eylül 2011 tarihinde http://www.kktcmerkezbankasi.org adresinden erişildi.

Kocacık, F. (2003). Bilgi toplumu ve Türkiye. Cumhuriyet Üniversitesi Sosyal Bilimler Dergisi, 27(1), $1-10$.

Odabaş, H. (2006). Bilgi yönetim. H. Odabaş ve H. Anameriç (Yay. Haz.). Bilgi.... içinde (ss. 99108). Ankara: Referans Yayıncılık. 10 Ağustos 2011 tarihinde http://eprints.rclis.org/ bitstream/10760/3844/1/12.pdf adresinden erişildi. 